JAPMAI Vol. 1, No. 1, September 2018, pp: 13 - 24
Journal of Applied Philosophical Management
and Innovation
https://journal.apmai.org/v2/index.php/japmai

\title{
THE EFFECTS OF HEDONIC VALUE, UTILITARIAN VALUE, AND CUSTOMER VALUE ON SATISFACTION AND BEHAVIORAL INTENTIONS
}

\author{
Lamidi., M.D. Rahadhini ${ }^{\bowtie}$
}

\begin{abstract}
Article's history
Received December 22, 2017

Revised March 9, 2018

Accepted March 28, 2018

Key words:

Hedonic, utilitarian, value, satisfaction, behavioral intention
\end{abstract}

\begin{abstract}
This study aims to examine the effects of hedonic value, utilitarian value, and customer value on satisfaction and behavioral intentions. Data were obtained from the survey by distributing questionnaires to respondents. This research applies a convenience sampling technique with the sample consisted of 110 respondents, i.e., the consumers of Timlo Sastro Solo. Data were analyzed by using Structural Equation Modelling (SEM) with Amos program. The findings of the research show that hedonic value, utilitarian value, and customer value have significant effects on satisfaction and behavioral intention through satisfaction. This research suggests Timlo Sastro Solo to maintain the quality of food taste, provide prompt service, maintain cleanliness, and arrange the restaurant layout to increase customer value towards the restaurant in order to increase consumer satisfaction so that the consumer will repurchase and recommend products to the others.
\end{abstract}

Lamidi, M.D. Rahadhini Faculty of Economics, University of Slamet Riyadi, Surakarta -

Indonesia

$\bowtie$ Corresponding author: lamidi71@gmail.com

\section{Introductions}

Culinary tourism is one of the main attractions for the tourist visiting the new area as each area has its own taste and variety of food. The culinary tour facility aims to introduce various foods to the public and provides convenience for tourists with minimal information and limited time to taste the special culinary in certain areas (Oetomo and Santoso, 2014). The presence of various culinary places raises competition in attracting consumers, especially in term of competitions of price, service, and variety of food in order to satisfy consumers. Consumers who are satisfied with the product will be loyal and considering to repurchase in the future (Putro, et al., 2014). Satisfaction is influenced by various factors and one of them is value.

Consumers enjoy the hedonic value when consuming the product; experience and product consumption related to feelings, fantasies, pleasures, and senses that affect one's emotion. Hedonic value is the overall evaluation of a consumer based on the fulfillment of pleasure (Yistiani, et al., 2012). The hedonic value is based on the buying motivation from within the consumers' self because they like the product and driven by the desire to achieve a form of pleasure, freedom, delusion, and escape from the problems. The consumption of a product or service can create a sense of fantasy, generate sense-based feelings, and 
generate emotional stimulation to satisfy oneself (Kang and Poaps, 2010; Bagyarta and Dharmayanti, 2014).

The benefit of the product or utilitarian value is also a consideration for the consumer in purchasing a product. Utilitarian value-oriented consumer behavior will select the product based on rational reasons (Hanzae and Rezaeyeh, 2013). According to Kim (2006), utilitarian value has two dimensions, namely efficiency and achievement. Efficiency is the needs of consumers in saving time and sources of funds, while achievement is the achievement of purchasing objectives by the finding of the products that have been planned previously.

The customer value is the difference between the customer's evaluation of all benefits and all the costs of a particular offer with the other alternatives in mind (Kotler and Keller, 2009). Research findings by Nejati and Moghaddam (2013), Irani and Hanzaee, (2011), Hanzaee and Rezaeyeh (2013), Shintaro (2009), and Ryu, et al (2010) stated that hedonic value and utilitarian value have a positive and significant influence on satisfaction and intention to buy, as well as repurchase intention. Customer value has not been much explored in previous studies in terms of influencing satisfaction and behavioral intention. Therefore, this research incorporates customer value in influencing satisfaction and behavioral intention. The customer value is based on the difference between what the customer earns and what is given for various possible options. Customer value is diverse because of the different norm factor in family, environment, purpose of life, future goals, and so on (Widiarso, 2011).

\section{Literature Review}

\section{Hedonic Value}

The hedonic value is based on the buying motivation from within the consumers' self because they like it, driven by the desire to achieve a form of pleasure, freedom, delusion, and escape from the problems. Hedonic consumption refers to the consumers needs of consuming a product to create a sense of fantasy, to generate sense-based feelings, and to produce emotional stimulation to satisfy themselves. The hedonic value is related to the fulfillment of pleasure or aesthetic aspects of a product (Blythe, 2005). The hedonic value is a stimulus that selects the quality of the shopping environment in terms of perceived enjoyment, visual appeal, and the escapism (Subagio, 2011).

There are six dimensions to measure the hedonic level of a consumer, namely adventure, social, gratification, idea, role, and value shoppings (Kim, 2006), as the followings:

a. Adventure shopping. Consumers shop because of the experience as if they have their own world when they shop.

b. Social shopping. Consumers assume that the pleasure in shopping will be created when consumers spend time with family or friends.

c. Gratification shopping. Shopping is one alternative to reduce stress, overcome and forget problems of life.

d. Idea shopping. Consumers shop to keep up with new fashion trends and to see new products or things.

e. Role shopping. Consumers prefer to shop for others rather than for themselves so that they feel that shopping for others is a fun thing to do.

f. Value shopping. Consumers think that shopping is a game when there is a price bargaining or when consumers are looking for a place that offers discounts, clearance sale, or low prices.

\section{Utilitarian Value}

Utilitarian value is a form of consumer attitudes where consumers shop by making purchases or not making purchases of products that have been determined rationally or 
based on their needs (Sari, 2014). The perception of utilitarian value depends on something that the consumer can achieve from the consumption activity. The utilitarian value is the consumer's evaluation towards the functional attributes of a product (Blythe, 2005). The utilitarian value is the impetus in a person to evaluate the motive in obtaining a quality product, and also efficiency of time and effort (Subagio, 2011).

Ailawadi, et al (2001) suggest that utilitarian benefits include saving, quality, and convenience benefits. These benefits help consumers to obtain optimal use of the product they purchases. However, customer satisfaction is a major factor in affecting purchase intensity and loyalty level. Consumer satisfaction is a consumer's response at a certain time after he/she likes the benefits of the product (Nejati and Moghaddam, 2013). There are two dimensions of utilitarian value, i.e., efficiency and achievement. Efficiency is defined as the needs of consumers in saving time and resources (fund), while achievement is defined as the achievement of the shopping goals in the form of finding of the products that have been planned previously (Kim, 2006).

Customer Value

Customer value is a thorough evaluation of the usefulness of a product based on consumer perceptions towards the amount of benefits to be received compared to the sacrifices made (Krisno and Samuel, 2013). The customer value is the perception of the value where the company considers that the value in developing the product is in line with the customer expectation (Gaffar, 2008). The value of the customer as a consumer's overall assessment of the utility of a product is based on the perception of what is received and what is given. Referring to Tjiptono (2006), there are four dimensions of value as the followings:

a. Emotional value, which is the utility derived from the feelings or the affective/positive emotions that result from consuming the product.

b. Social value, which is the utility derived from the product's ability to improve the consumer's social-self concept.

c. Quality/performance value, which is the utility derived from the perception of the expected performance of a product or service.

d. Price/value of money, which is the utility derived from products due to the reduction of short-term cost and long-term cost.

$\underline{\text { Satisfaction }}$

Customer satisfaction is the consumer's feeling after experiencing the performance of a company that matches his expectations (Kotler, 2008). Satisfied customers tend to remain loyal, buy more, and less sensitive to price changes. Satisfaction is the response of consumers to the fulfillment of needs, which means that consumer evaluation towards a product provides the comfort level related to the fulfillment of needs, including the fulfillment of needs that are not as expected or fulfillment that exceeds expectations (Barnes, 2003).

Satisfaction is a behavioral response in the form of post-purchase evaluation of the appearance and performance of a product perceived by consumers compared to the wants, needs, and expectations towards the product. Satisfaction is strongly influenced by consumers' perceptions and expectations towards the product. The factors that affect satisfaction are services, equipment or facilities, employee education, and effective handling of consumers' complaints (Tjiptono, 2006).

According to Tjiptono (2006), there are several methods that can be used to measure and monitor customer satisfaction as follows:

a. Complaints and suggestion system.

Companies should give customers the opportunity to submit suggestions, opinions, and complaints. The mediums used include strategically placed suggestion box, direct comment cards or postcards, or providing a special telephone line.

b. Customer satisfaction survey. 
From the survey the company will get direct response and feedback. It is also a positive signal that the company is paying attention to its service.

c. Ghost shopping.

This method is applied by hiring some people (ghost shoppers) to act as customers or potential buyers of the company's and competitors' products. Then, the ghost shopper conveys the strengths and weaknesses of the company's and competitors' product based on their experience in purchasing the product.

d. Cost customer analysis

This method is a bit unique as the company tries to contact its customers who have stopped buying or who have switched to other companies.

\section{Behavioral Intention}

Behavioral intention is a consumer's intention to behave in a certain way in order to own, dispose, and use the product. Consumers can form their intention to seek information, notify others of their experience with a product, buy a particular product, or dispose of a product in a certain way (Mowen and Minor, 2012). Behavioral intention is the frequency of purchases or the proportion of total purchases from buyers who are loyal to a particular brand (Schiffman and Kanuk, 2010). There are four dimensions of the behavioral intention, namely: word of mouth, price sensitivity, repeat purchasing, and customer loyalty (Parasuraman, et al. 2006). Behavioral intention is an indication of someone willing to try and instill trust in the company so that it brings its own satisfaction. Behavioral intention is a proportion connected to the upcoming action (Olson and Peter, 2008).

This research develops the following hypotheses:

H1 : Hedonic value affects consumer satisfaction.

H2 : Utilitarian value affects consumer satisfaction.

H3 : Customer value affects consumer satisfaction.

H4 : Hedonic value affects consumer behavioral intention.

H5 : Utilitarian value affects consumer behavioral intention.

H6 : Customer value affects consumer behavioral intention.

H7 : Satisfaction affects consumer behavioral intention.

H8 : Hedonic value affects consumer behavioral intention through customer satisfaction.

H9 : Utilitarian value affects consumer behavioral intention through customer satisfaction.

H10 : Customer value affects consumer behavioral intention through customer satisfaction.

\section{Method}

Population and Sample

Population is a collection of individuals, events, or other interesting things to be studied (Sekaran, 2006). The population of this study is the consumers of Timlo Sastro Solo. This study uses non-probability sampling, because the population number is unknown. Using the convenience sampling technique, the sample of this research is consisted of 110 consumers of Timlo Sastro Solo. The sample is taken when the consumers making the purchase in Timlo Sastro Solo.

Data Collecting Method

Data of this study are primary data obtained directly from the respondents and secondary data obtained from the relevant literatures. Data collection is performed by distributing questionnaires to the respondents. The questionnaire consists of a list of determined 
questions and clearly defined alternative answers (Sekaran, 2006). The research instrument is measured by Likert scale, using 5 (five) points of strongly disagree to strongly agree. Data analysis is performed using Structural Equation Modeling (SEM) with Amos program. Validity testing is performed by Confirmatory Factor Analysis (CFA), while reliability testing is referring to Cronbach's Alpha. In running a SEM analysis, the following assumptions should be met:

Table 1. Goodness of Fit Index

\begin{tabular}{clc}
\hline No & \multicolumn{1}{c}{ Goodness of Fit Index } & Cut-off Value \\
\hline 1 & Chi-Square & Lower value \\
2 & Significance & $\geq 0.05$ \\
3 & RMSEA & $\leq 0.08$ \\
4 & GFI & $\geq 0.90$ \\
5 & AGFI & $\leq 0.90$ \\
6 & CMIN/ DF & $\leq 2.00$ \\
7 & TLI & $\geq 0.95$ \\
8 & CFI & $\geq 0.94$ \\
\hline
\end{tabular}

Source: Ferdinand (2014)

The operational definitions of each research variable are the followings:

1. Hedonic value

The hedonic value is the overall evaluation of the consumer based on the fulfillment of pleasure. The indicators used are referring to Hanzae and Rezaeyeh's research (2013), which consist of having good feelings, very pleasant, valuable experience, feeling joy, and liking a better place even though the price is higher than the others.

2. Utilitarian value

Utilitarian value is the selection of products made by consumers efficiently based on rational reasons. The indicators used are referring to Hanzae and Rezaeyeh's research (2013), which consist of reasonable food prices, good taste of food, adequate food portions, a variety of menu options, and healthy food choices.

3. Customer value

Customer value is the result of a comparison between the overall benefits consumers perceive and the sacrifices they made. Indicators used are based on Jang's (2015) study, consisting of good quality, good taste, reasonably economical price, have a good reputation.

4. Satisfaction

Satisfaction is the consumer's response to the fulfillment of needs which means that the consumer's assessment of the product provides the level of comfort associated with the fulfillment of needs, including the fulfillment of needs that does not meet the expectations or fulfillment of needs that exceeds the expectations. The indicators used are referring to Hanzae and Rezaeyeh's (2013) research consisting of: very pleasant, not disappointing, happy mood, and feeling of comfort.

5. Behavioral intention

Behavioral intention is an indication of someone willing to try and instill trust toward the company that brings its own satisfaction. The indicators used are referring to Hanzae and Rezaeyeh's research (2013) consisting of: desire to revisit, recommending products to the others, frequent visits, and inviting others. 
Vol. 1, No. 1, 2018, pp. 13 - 24

\section{Results and Discussion}

Characteristics of Respondents

Table 2. Characteristic of Respondents

\begin{tabular}{|c|c|c|}
\hline Gender & Frequency & Percentage (\%) \\
\hline Male & 56 & 50,9 \\
\hline Female & 54 & 49,1 \\
\hline Total & 110 & 100 \\
\hline \multicolumn{3}{|l|}{ Age } \\
\hline$<30$ years old & 25 & 22,7 \\
\hline $31-40$ years old & 53 & 48,2 \\
\hline$>40$ years old & 32 & 29,1 \\
\hline Total & 110 & 100 \\
\hline \multicolumn{3}{|l|}{ Educational Background } \\
\hline Junior High School Graduates & 7 & 6,4 \\
\hline Senior High School Graduates & 35 & 31,8 \\
\hline Diploma Graduates & 34 & 30,9 \\
\hline University Graduates & 34 & 30,9 \\
\hline Total & 110 & 100 \\
\hline \multicolumn{3}{|l|}{ Occupation } \\
\hline Student & 11 & 10,0 \\
\hline Army/Policeman & 14 & 12,7 \\
\hline Civil Servant & 31 & 28,1 \\
\hline Entrepreneur & 54 & 49,1 \\
\hline Total & 110 & 100 \\
\hline
\end{tabular}

Source: primary data, 2017

\section{Validity and Reliability Tests}

The validity test is performed using CFA. The test result shows the estimate value $>0.50$ so that the research instrument is feasible to use. Reliability test is based on Cronbach's alpha. The results show that all research variables (hedonic value, utilitarian value, customer value, customer satisfaction, and behavioral intention) are reliable because the Cronbach's alpha values are $>0.60$ as presented in the following table:

Table 3. Results of Reliability Test

\begin{tabular}{lc}
\hline \multicolumn{1}{c}{ Variable } & Cronbach`s Alpha \\
\hline Hedonic Value & 0.717 \\
Utilitarian Value & 0.872 \\
Customer Value & 0.624 \\
Consumer Satisfaction & 0.674 \\
Behavioral Intention & 0.766 \\
\hline
\end{tabular}

Source: primary data, 2017

\section{Goodness of Fit}

The Goodness of Fit (GFI) test is used to observe whether the model with the required assumptions to be analyzed with SEM. The GFI test results are shown below. 
Table 4. Goodness of Fit Index

\begin{tabular}{cccc}
\hline GFI Index & Cut-off Value & Results & Model Evaluation \\
\hline Chi-Square & $\chi^{2}$ close to 0 & 233.629 & - \\
Probability & $\geq 0.05$ & 0.063 & Good fit \\
GFI & $\geq 0.90$ & 0.849 & Marginal \\
AGFI & $\geq 0.90$ & 0.812 & Marginal \\
TLI & $\geq 0.95$ & 0.945 & Good fit \\
CFI & $\geq 0.95$ & 0.952 & Good fit \\
RMSEA & $\geq 0.08$ & 0.038 & Good fit \\
CMIN/DF & $\leq 2.0$ & 1.157 & Good fit \\
\hline
\end{tabular}

Source: primary data, 2017

The structural model shows that the Chi-square value in the full model is 233,629 . The CMIN/DF, TLI, CFI, and RMSEA values indicate that the model fits the required criteria, although the GFI, AGFI score is in marginal condition. So, it can be concluded that the model is fit and feasible to use.

\section{Hypothesis Testing}

Hypothesis testing using SEM is by analyzing the regression value (regression weight analysis). It is performed by analyzing the critical ratio (CR value >1.96) and probability value $(\mathrm{p}<0.05)$. The regression weights results are shown in the following table:

Table 5. Results of Regression Weights

\begin{tabular}{lccccccl}
\hline & & & Estimate & S.E. & C.R. & p & \multicolumn{1}{c}{ Lable } \\
\hline KP & $<---$ & NH & .191 & .093 & 2.064 & .039 & Significant \\
KP & $<---$ & NU & .165 & .074 & 2.233 & .026 & Significant \\
KP & $<---$ & NP & .295 & .126 & 2.347 & .019 & Significant \\
NB & $<---$ & KP & .547 & .236 & 2.316 & .021 & Significant \\
NB & $<---$ & NH & .265 & .114 & 2.329 & .020 & Significant \\
NB & $<---$ & NP & .387 & .161 & 2.405 & .016 & Significant \\
NB & $<---$ & NU & .176 & .087 & 2.029 & .042 & Significant \\
\hline
\end{tabular}

Source: primary data, 2017

From the results of hypothesis testing, it be can be explained as follows:

Hedonic value, utilitarian value, and customer value affect consumer satisfaction

1. The effect of hedonic value on customer satisfaction

There is a significant effect of hedonic value on consumer satisfaction as the obtained CR value is $2.064>1.96$ and $\mathrm{p}$ value is $0.039<0.05$. Thus, hypothesis 1 as accepted. These results support the research of Nejati and Moghaddam (2013) stating that hedonic value has a significant effect on satisfaction. The hedonic value is based on the buying motivation that arises from within the consumer's self because the consumer likes it and it is driven by the desire to achieve pleasure, freedom, delusion, and escape from problems. The implication of this research is that Timlo Sastro Solo needs to maintain the quality of its food taste to keep their consumers satisfied.

2. The effect of utilitarian value on consumer satisfaction

There is a significant effect of utilitarian value on consumer satisfaction as the obtained CR value is $2.233>1.96$ and $\mathrm{p}$ value is $0.026<0.05$. Thus, hypothesis 2 is accepted. The results of this study support the research of Irani and Hanzaee (2011), Hanzaee and Rezaeyeh (2013), and Shintaro (2009) which stated that utilitarian value has a significant effect on consumer satisfaction. Utilitarian value-oriented consumers will choose products efficiently based on rational reasons. The implication of this research is 
that Timlo Sastro Solo needs to pay attention to consumer convenience by providing services that make their consumers happy and feel that purchasing in Timlo Sastro Solo is the right choice.

3. The effect of customer value on customer satisfaction

There is a significant influence of customer value on consumer satisfaction as the obtained CR value is $2.347>1.96$ and $p$ value is $0.019<0.05$. Thus, hypothesis 3 is accepted. These results support the research of Christianto (2012) which shows that customer value affects customer satisfaction. The higher the value obtained, the more positive the customer value towards the purchased product. Conversely, the lower the value obtained, the more negative the customer value towards the purchased product. The implication of this research is that Timlo Sastro Solo needs to maintain the cleanliness of the dining area, arrange the layout of the dining area, improve the decoration of the dining area by providing comfortable tables and chairs, and sending signals to improve customer value.

Hedonic value, utilitarian value, and customer value affect behavioral intention

\section{The effect of hedonic value on behavioral intention}

There is a significant effect of hedonic value on behavioral intention as the obtained value of $C R$ is $2.329>1.96$ and $p$ value is $0.020<0.05$. Thus, hypothesis 4 is accepted. The results of this study support the research of Nejati and Moghaddam (2013) which states that the hedonic value affects the intention to buy. The implication of this research is that Timlo Sastro Solo should have good product quality so that consumers do not hesitate to make repurchase.

2. The effect of utilitarian value on behavioral intention

There is a significant effect of utilitarian value on behavioral intention as the obtained $\mathrm{CR}$ value is $2.029>1.96$ and $\mathrm{p}$ value is $0.042<0.05$. Therefore, hypothesis 5 is accepted. The results of this study support the research of Nejati and Moghaddam (2013) stating that the utilitarian value influences the desire to buy. The implication of this research is that Timlo Sastro Solo needs to increase the speed in serving the orders from its consumers.

3. The effect of customer value on behavioral intention

There is a significant effect of customer value on behavioral intention as the obtained $\mathrm{CR}$ value is $2.405>1.96$ and $\mathrm{p}$ value is $0.016<0.05$. Therefore, hypothesis 6 is accepted. The results of this study support the research of Christianto (2012) which shows that the customer value affects behavioral intention. The implication of this research is that Timlo Sastro Solo should understand the consumer behavior and create an attractive restaurant to be visited by consumers, such as by arranging a comfortable space as possible in order to provide a memorable room atmosphere for the visitors.

\section{Consumer satisfaction affects behavioral intention}

There is a significant effect of consumer satisfaction on behavioral intention as the obtained CR value is $2.316>1.96$ and $\mathrm{p}$ value is $0.021<0.05$. Thus, hypothesis 7 is accepted. These results support the research of Kartika (2012) stating that satisfaction has a significant effect on behavioral intention. The implication of this research is that Timlo Sastro Solo is expected to provide the convenience for the consumers in ordering food by making the ordering system faster so that consumers will feel comfort while waiting for the food. By minimizing the feeling of bored while waiting for the food, the consumer will be more satisfied in terms of food, time, and the cost they spent. 
Hedonic value, utilitarian value, and customer value affect behavioral intention through customer satisfaction

The magnitude of the effect of each latent variable directly (standardized direct effect) and indirectly (standardized indirect effect) and the total effect (standardized total effect) is described in Table 6.

Table 6. Standardized Direct Effect-Estimates

\begin{tabular}{llllll}
\hline & NP & NU & NH & KP & NB \\
\hline KP & .394 & .278 & .292 & .000 & .000 \\
NB & .376 & .215 & .294 & .398 & .000 \\
\hline
\end{tabular}

Source: primary data, 2017

The direct effect of hedonic value on consumer satisfaction is 0.292 , the direct effect of utilitarian value on consumer satisfaction is 0.278 , and the direct effect of customer value on consumer satisfaction is 0.394 . The direct effect of hedonic value on behavioral intention is 0.294 , the direct effect of utilitarian value on behavioral intention is 0.215 , and the direct effect of customer value on behavioral intention is 0.376 .

Table 7. Standardized Indirect Effect-Estimates

\begin{tabular}{llllll}
\hline & NP & NU & NH & KP & NB \\
\hline KP & .000 & .000 & .000 & .000 & .000 \\
NB & .157 & .111 & .116 & .000 & .000 \\
\hline
\end{tabular}

Source: primary data, 2017

Table 7 shows that there are no indirect effects of hedonic value, utilitarian value, and customer value on customer satisfaction, whereas the indirect effect of hedonic value on behavioral intention is 0.116 , the indirect effect of utilitarian value on behavioral intention is equal to 0.111 , and the indirect effect of customer value on behavioral intention is equal to 0.157 .

Table 8. Standardized Total Effect-Estimates

\begin{tabular}{llllll}
\hline & NP & NU & NH & KP & NB \\
\hline KP & .394 & .278 & .292 & .000 & .000 \\
NB & .532 & .326 & .410 & .398 & .000 \\
\hline
\end{tabular}

Source: primary data, 2017

Table 8 shows that the effect of total hedonic value on consumer satisfaction is 0.292 (equal to direct effect), the effect of total utilitarian value on behavioral intention is 0.326 (equal to direct effect) and the effect of total customer value on consumer satisfaction is 0.394 (equal to direct effect), while the effect of total hedonic value on behavioral intention is 0.410 , the effect of total utilitarian value on behavioral intention is 0.326 , and the effect of total customer value on behavioral intention is 0.532 . These findings suggest that hedonic value, utilitarian value, and customer value affect behavioral intention through consumer satisfaction. Thus, hypotheses 8,9 , and 10 are accepted. The results of this study support the research of Ryu, Han, and Jang (2010) stating that hedonic value and utilitarian value affect satisfaction and repurchase intention.

The implication of this research is that Timlo Sastro Solo is expected to maintain the good image and the neat and the hygienic restaurant condition, provide new alternative menu, attractive room arrangement, and make sure that the consumers feel comfort so that they will revisit the restaurant in the future. Friendly and professional employees in providing 
services can also make consumers feel comfortable that will affect consumer's tendency to repurchase and recommend the product to others.

\section{Conclusion}

Referring to the results of the study, it can be concluded that hedonic value, utilitarian value, and customer value are important in encouraging consumers' behavioral intention. The hedonic value is based on purchasing motivation that arises from within the consumers' self because they like it, driven by the desire to achieve a form of pleasure. Therefore, Timlo Sastro Solo should maintain the quality of the food taste to satisfy its consumers. Utilitarian value-oriented consumers will choose products efficiently based on rational reasons. Timlo Sastro Solo should also pay attention to provide convenience to consumers by providing services that make them happy and feel that buying products in Timlo Sastro Solo is the right choice. The higher the value obtained, the more positive the customer value towards the product purchased. It is expected that Timlo Sastro Solo will keep maintaining its cleanliness, setting the attractive layout of the restaurant, improving the design of the dining area in order to keep consumers satisfied.

Consumer satisfaction mediates the effect of hedonic value, utilitarian value, and customer value on behavioral intention. Timlo Sastro Solo should maintain the quality of the food taste, provide prompt service, maintain the cleanliness, and arrange the layout to improve customer value toward the restaurant so that the consumer satisfaction increased that will finally affect consumer re-purchase intention and recommendation to others.

\section{References}

Ailawadi KL, Lehmann DR, Neslin SA. 2001. Market Response to A Major Policy Change in the Marketing Mix: Learning from Procter \& Gamble's Value Pricing Strategy. Journal Marketing 65(1): 44-61.

Babin. 1994. Work and or Fun: Measuring Hedonic and Utilitarian Shopping Value. Journal of Consumer Research, Vol 20, p. 91-10.

Bagyarta, Samsi Dimastita dan Diah Dharmayanti. 2014. Pengaruh Hedonic dan Utilitarian Value terhadap Repurchase Intention Pada Industri Pusat Kebugaran Kelas Menengah Atas di Sidoarjo. Jurnal Manajemen Pemasaran Petra. Vol 2 No 1, h. 132-145.

Barnes, James G. 2003. Secrets of Customer Relationship Management. Andi. Yogyakarta. Blythe, J. 2005. Essentials of Marketing. Pearson Education Limited. England.

Cramer L, Antonide G. 2011. Endowment Effects for Hedonic and Utilitarian Food Products. Journal Food Quality and Preference. Vol. 22: 3-10.

Christianto, Sova Adi. 2012. Pengaruh Service Quality, Food Quality dan Perceived Value pada Behavioural Intention yang Dimediasi oleh Customer Satisfaction (Studi pada Restoran Ayam-Ayam Resto Klodran). Tesis. Fakultas Ekonomi Universitas Sebelas Maret Surakarta.

Ferdinand, A. 2014. Structural Equation Modeling Dalam Penelitian Manajemen. Fakultas Ekonomi Universitas Diponegoro. Semarang.

Ghozali, Imam, 2011.Aplikasi Analisis Multivariate dengan Program SPSS. Badan Penerbit Universitas Diponegoro. Semarang.

Hair, J.F. et al, .2010. Multivariate Data Analysis with Readings, McMillan. Publishing. New York. 
Hanzae, K.H., dan Rezaeyeh, S.P. 2013. Investigation of The Effects of HedonicValue and Utilitarian Value on Customer Satisfaction and Behavioural Intentions. African Journal of Business Management, 7 (11), 818-825.

Jang, Yisak. 2015. Perceived Value of Fast-Food Restaurant Franchises in the USA. Thesis. Master of Science in Hospitality Management. Florida International University.

Kartika, Gilang Widya. 2012. Analisis Pengaruh Hedonic Value dan Utilitarian Value Terhadap Kepuasan Konsumen, dan Behavioral Intentions, Pada Industri Fast-Casual Restaurant Studi Pada Restoran Social House. Tesis. Unpublication: Universitas Indonesia.

Kang, Jiyun dan Poaps, Haesun Park. 2010. Hedonic and Utilitarian Shopping Motivations of Fashion Leadership. Journal of Fashion Marketing and Management: An International Journal Vol. 14 Issue 2, p.312 - 328.

Kim, H.S. 2006. Using Hedonic and Utilitarian Shopping Motivations to Profile Inner City Consumers. Journal of Shopping Center Research, 13 (1), p. 57-79.

Kotler, Philip. 2008. Manajamen Pemasaran. Indeks. Jakarta.

Kotler, Philip. dan Keller, Kevin Lane. 2009. Manajemen Pemasaran. Alih Bahasa oleh Benyamin Molan. Indeks. Jakarta.

Kotler dan Armstrong. 2010. Prinsip-Prinsip Pemasaran. Erlangga. Jakarta.

Krisno dan Samuel. 2013. Pengaruh Persepsi Kualitas Perceived Sacrifie and Perceived Value Terhadap Customer Satisfaction Di Informa Innovative Furnishing Pakuwon. Jurnal Manajemen Petra. Vol 1, h. 1-12.

Mowen, J C. dan Michael Minor. 2012. Perilaku Konsumen. Erlangga. Jakarta.

Nejati M, Moghaddam PP. 2013. The Effect of Hedonic and Utilitarian Values on Satisfaction and Behavioural Intentions for Dining in Fast-Casual Restaurants in Iran. British Food Journal. Vol 115(11), p. 1583-1596.

Nugroho Adi Wahyu dan Budi Sudaryanto. 2013. Pengaruh Kinerja Layanan, Kepercayaan dan Kepuasan Terhadap Loyalitas Konsumen Jasa Pengiriman Barang. Diponegoro Journal of Management. Vol 2 No 3 p.1-9.

Ryu, Kisang, Heesup Han and Soocheong (Shawn) Jang. 2010. Relationships among hedonic and utilitarian values, satisfaction and behavioral intentions in the fast-casual restaurant industry. International Journal of Contemporary Hospitality Management Vol. 22 No. 3, p. 416-432.

Tjiptono, Fandi. 2006. Pemasaran Jasa. Andi. Yogyakarta.

T. S. Kaihatu. 2012. Kepuasan Konsumen yang Dipengaruhi oleh Kualitas Layanan dengan Brand Image Sebagai Variabel Perantara: Studi Kasus pada Konsumen Rumah Sakit Swasta di Kota Surabaya. Jurnal Mitra Ekonomi dan Manajemen Bisnis. Vol 3 No 2, h. 200-210.

Oetomo, Anthony dan Kuntjoro Santoso. 2014. Fasilitas Wisata Kuliner Solo di Solo Baru. Jurnal e-dimensi Arsitektur. Vol. II, No. 1, h. 316-320.

Peter, J. Paul dan Jerry C. Olson. 2008. Perilaku Konsumen dan Strategi Pemasaran. Alih Bahasa: Damos Sihombing, MBA dan Peter Rem Yossi Pasla, Erlangga. Jakarta.

Putro, Shandy Widjoyo, Hatane Semuel, Ritzky Karina M.R. Brahmana. 2014. Pengaruh Kualitas Layanan dan Kualitas Produk terhadap Kepuasan Pelanggan dan Loyalitas Konsumen Restoran Happy Garden Surabaya. Jurnal Manajemen Pemasaran. Vol.2, No. 1, h. 1-9.

Sari, Sinta Puspita. 2014. Faktor Utilitarian dan Hedonis terhadap Loyalitas Melalui Kepuasan Pelanggan Pada Hotel Ibis. Jurnal Ilmu dan Riset Manajemen. Vol. 3 No. 6, h. 1-15. 
Schiffman dan Kanuk. 2010. Perilaku Konsumen. Index. Jakarta.

Sekaran, Uma. 2006. Research Methods for Business (Metodologi Penelitian Untuk Bisnis). Salemba Empat. Jakarta.

Subagio, H. 2011. Pengaruh Atribut Supermarket terhadap Motif Belanja Hedonik Motif Belanja Utilitarian dan Loyalitas Konsumen. Jurnal Manajemen Pemasaran, Vol 6 (1), April: 8-21.

Yistiani, Ni Nyoman Manik, Ni Nyoman Kerti Yasa dan I G. A. Ketut Gede Suasana. 2012. Pengaruh Atmosfer Gerai dan Pelayanan Ritel terhadap Nilai Hedonik dan Pembelian Impulsif Pelanggan Matahari Department Store Duta Plaza di Denpasar. Tesis. Program Pascasarjana Universitas Udayana Denpasar. Jurnal Manajemen, Strategi Bisnis, dan Kewirausahaan Vol. 6 No. 2, h. 139-149. 